Experimental Cell Research 60 (1970) 115-118

\title{
PROTEIN SYNTHESIS BEFORE AND AFTER FERTILIZATION IN THE EGG OF ILYANASSA OBSOLETA
}

\author{
P. E. MIRKES \\ Department of Zoology, The University of Michigan, Ann Arbor, Mich. 48104, USA
}

\begin{abstract}
SUMMARY
Protein synthesis before and after fertilization in Ilyanassa obsoleta has been investigated. Unfertilized eggs do incorporate significant amounts of labelled amino acids into protein. However; fertilized eggs undergo an increase both in uptake and incorporation of labelled amino acids into protein within 15 minutes of fertilization. Post-fertilization protein synthesis is sensitive to but not completely inhibited by puromycin.
\end{abstract}

Although the activation of protein synthesis after fertilization has been investigated in the eggs of a variety of species, generalizations concerning the activation process have been developed almost solely from information gained from experiments with sea urchins. In sea urchins the entry of the sperm occurs after meiosis has been completed. In other animals studied sperm entry occurs during earlier phases of meiosis: the nemertine Cerebratulus lacteus in first metaphase; the echiuroid Urechis caupo-the germinal vesicle stage; the mollusc Spisula solidissima -germinal vesicle; the chordate Rana pipiens -at second metaphase, and the echinoderm Asterias forbesii-after breakdown of the germinal vesicle. Evidence from experiments with these animals indicates that the generalizations do not always apply. This report concerns post-fertilization protein synthesis in Ilyanassa obsoleta, a gastropod mollusc, in which fertilization occurs at the germinal vesicle stage of maturation.

\section{METHODS}

Unfertilized eggs were obtained from egg capsules laid by females isolated prior to copulation. Eggs removed from cleaned capsules were then fertihized by sperm obtained from the testis and diluted 2:1 with Millipore-filtered sea water (MFSW). Ten drops of this diluted sperm suspension were added to each $15 \mathrm{ml}$ of MFSW containing the eggs. After a 3-5 min exposure, the fertilized eggs were washed four times with MFSW which removed excess sperm. Alternately, eggs in capsular jelly were fertilized within an opened capsule. With either method $75-$ $95 \%$ fertilization was routinely obtained. The fertilization of eggs and subsequent culture of embryos were carried out in MFSW containing Sodium Sulfadiazine $(50 \mathrm{mg} / \mathrm{l})$ and Streptomycin Sulfate $(50 \mathrm{mg} / \mathrm{l}$, hereafter termed Abiotic Sea Water (ASW). Incubation temperature was maintained at $21 \pm 1^{\circ} \mathrm{C}$.

After exposure to ${ }^{3} \mathrm{H}$-leucine, eggs were washed four times with ice-cold ASW with gentle centrifugation. After the fourth wash $0.5 \mathrm{ml}$ of distilled water was added to each sample and eggs homogenized. Two $0.1 \mathrm{ml}$ samples of the homogenate were pipetted onto filter paper and air-dried. One $0.2 \mathrm{ml}$ sample was taken for determination of protein concentration by the phenol-copper method of Lowry et al. [4]. One of the filter papers was placed, without further treatment, into a counting vial with scintillation fluid (4 mg Omnifluor/liter Toluene). The other was treated with cold TCA for $2 \mathrm{~h}$, hot TCA $\left(90^{\circ} \mathrm{C}\right)$ for $15 \mathrm{~min}$, a propanol-ether $(1: 1)$ wash and an ether wash. The filter paper was placed in a counting vial and all samples were counted in a Beckman Liquid 


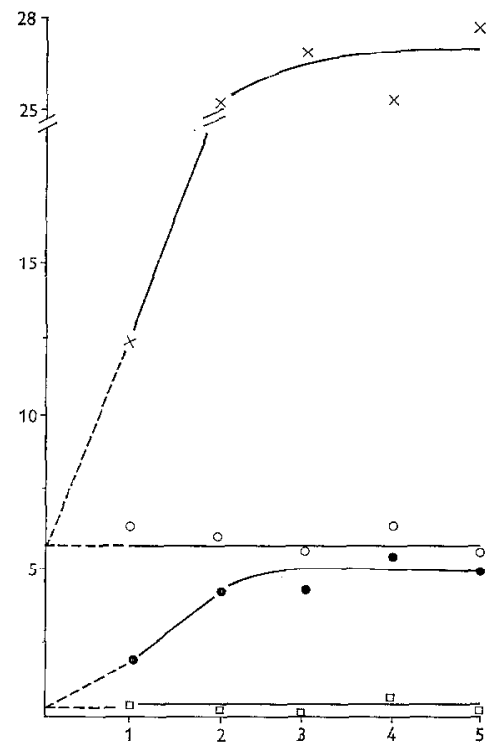

Fig. 1. Abscissa: hours after fertilization; ordinate: CPM $/ \mu$ g protein $\left(\times 10^{-1}\right) . \times-\times$, uptake by fertilized eggs, $\mathrm{O}-\mathrm{O}$, uptake by unfertilized eggs; incorporation by fertilized eggs, $\square-\square$, incorporation by unfertilized eggs. All points are mean values of 3 experiments. Hatched lines are extrapolations to zero time.

Uptake and incorporation of ${ }^{3} \mathbf{H}$-leucine by fertilized and unfertilized eggs. Samples of 300 fertilized and unfertilized eggs were exposed for $20 \mathrm{~min}$ to $30 \mu \mathrm{Ci} / \mathrm{ml}{ }^{3} \mathrm{H}$-leucine (40 $\mathrm{Ci} / \mathrm{mM}$, Schwartz Bioresearch) at hourly intervals after fertilization.

Scintillation Counter model LS-250 for $20 \mathrm{~min}$ per sample. Counts obtained from the untreated samples were taken as a measurement of total uptake of the labelled amino acid while counts obtained from the TCA-organic solvent treated samples were taken as a measurement of incorporation of the labelled amino acid into protein.

\section{RESULTS AND DISCUSSION}

A direct comparison of total uptake of ${ }^{3} \mathrm{H}$ leucine and its incorporation into protein in fertilized and unfertilized eggs is shown in fig. 1. Both uptake and incorporation of labelled leucine by unfertilized eggs maintain a constant level throughout the $5 \mathrm{~h}$ studied. However, in the fertilized eggs uptake and incorporation of ${ }^{3} \mathrm{H}$-leucine both show a definite increase as a result of fertilization and subsequently reach a maximum 2 hours after fertilization. The increased uptake of ${ }^{3} \mathrm{H}$-leucine which occurs after fertilization has been reported for various animals [3, 5-8] and seems to be a general feature of the fertilization reaction. This increased uptake by fertilized eggs could be the result of a general change in permeability of egg membrane or the activation of an active transport system for amino acids. Since the Ilyanassa embryo is a closed system with respect to amino acid supply, the former is the more probable.

The observation that protein synthesis is stimulated as a result of fertilization is complicated by the concomitant increase in uptake of the labelled precursor by fertilized eggs. To gain a more precise estimate of the protein synthesizing activity in fertilized and unfertilized eggs the data from fig. 1 are plotted as percent incorporation in fig. 2 . Percent incorporation is calculated by dividing the amount of ${ }^{3} \mathrm{H}$-leucine incorporated into protein by the amount of ${ }^{3} \mathrm{H}$-leucine taken up by the eggs. This calculation

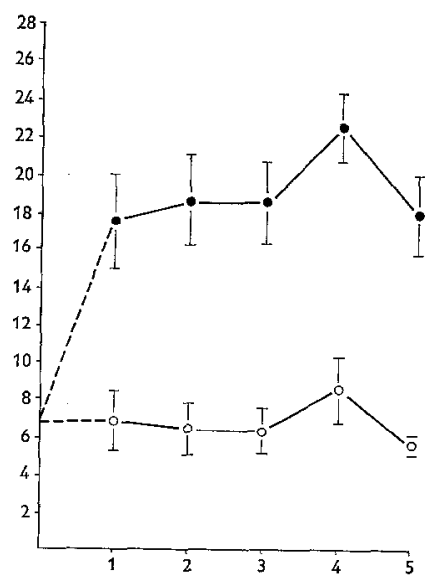

Fig. 2. Abscissa: hours after fertilization; ordinate: $\%$ incorporation. - $\bullet$, fertilized eggs; $0-0$, unfertilized eggs.

Percent incorporation by fertilized and unfertilized eggs. Hatched lines about each point indicate \pm 1 standard error; $n=5$ for fertilized, $n=3$ for unfertilized eggs. 
compensates for differences in incorporation rates due to changes in uptake of the labelled amino acid. Measured in this manner the protein synthesizing activity of fertilized eggs is 2.5 times greater than the activity of the unfertilized eggs. This increase in protein synthesis could be the result either of an increased efficiency of those ribosomes active before fertilization or a mobilization of previously inactive ribosomes. It is also important to point out that unfertilized eggs do synthesize protein but at a reduced level.

In order to reduce further the uncertainties resulting from pulse-labelling experiments, unfertilized eggs were "pre-loaded" with ${ }^{3} \mathrm{H}$-leucine and half of the eggs fertilized. This design eliminates the problem of permeability changes and presents equal amounts of the labelled precursor to all eggs. The data shown in fig. 3 present convincing evidence that the rise in protein synthesis, which occurs within the first $15 \mathrm{~min}$ after fertilization, is the result either of an increased efficiency of the protein synthesizing machinery or the utilization of previously inactive ribosomes and not a stimulation due simply to the greater availability of the labelled precursor. It is not immediately clear why the rate of protein synthesis, i.e., percent incorporation/ time, shows a decrease after the initial increase. The decline in rate could be the result of (1) a rapid depletion of the labelled amino acid due to the rapid initial increase in protein synthesis, (2) a preferential utilization of a small pool containing the labelled amino acids by fertilized eggs but not unfertilized eggs leading to a rapid dilution, (3) a change in the rate of protein synthesis after the initial increase, or (4) an early initiation of the breakdown of existing proteins leading to a dilution of the labelled precursor pool. The latter has some support from Collier [2] who has reported that the total amino acid

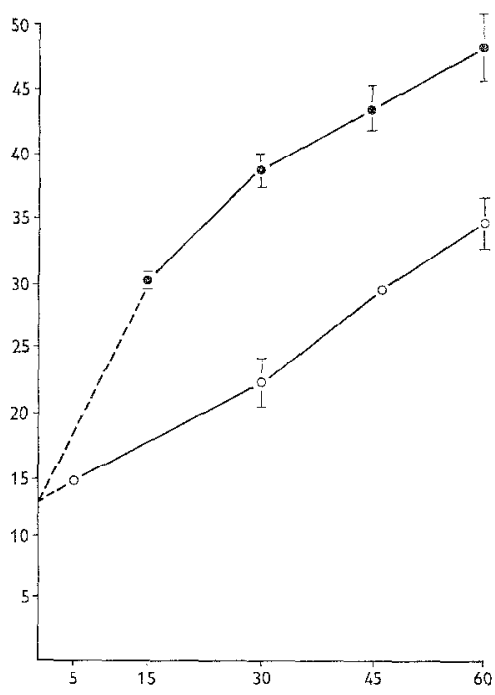

Fig. 3. Abscissa: minutes after fertilization; ordinate: $\%$ incorporation. - fertilized eggs; $0-0$, unfertilized eggs. Horizontal lines about points indicate the ranges. Hatched lines as indicated in fig. 1 .

Percent incorporation for fertilized and unfertilized eggs preloaded with ${ }^{8} \mathrm{H}$-leucine. Unfertilized eggs were exposed to ${ }^{3} \mathrm{H}$-leucine $(30 \mu \mathrm{Ci} / \mathrm{ml}$ for $25 \mathrm{~min}$ or $10 \mu \mathrm{Ci} / \mathrm{ml}$ for $45 \mathrm{~min}$ ) prior to fertilization. The labelled eggs were washed 5 times and then some were fertilized and some left unfertilized. At varions intervals after fertilization samples from each group were analyzed.

pool in Ilyanassa does not change during the first 3 days of development indicating that the synthesis of new protein and breakdown of pre-existing protein are regulated so that the necessary pool of amino acids is maintained. Such regulation would lead to an increasing dilution of the labelled precursor in the pool. However, since the decline in rate is apparent at $30 \mathrm{~min}$ after fertilization, a more likely explanation is the rapid dilution. of the labelled precursor in the pool as the result of the increased protein synthesis.

The effects of various concentrations of puromycin, and inhibitor of protein synthesis, are plotted in fig. 4. Protein synthesis is repressed $50 \%$ after a $2.5 \mathrm{~h}$ exposure to 200 $\mu \mathrm{g} / \mathrm{ml}$ of puromycin. Increasing the concentration to $400 \mu \mathrm{g} / \mathrm{ml}$ yields only about $60 \%$ 


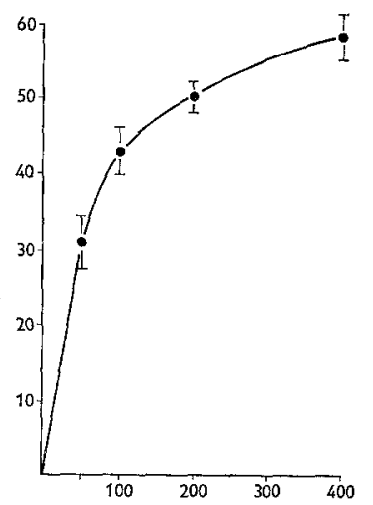

Fig. 4. Abscissa: $\mu \mathrm{g} / \mathrm{ml}$ puromycin; ordinate: $\%$ inhibition of protcin synthesis.

Effect of puromycin on protein synthesis by fertilized eggs. Fertilized eggs were exposed to puromycin $(50,100,200$, and $400 \mu \mathrm{g} / \mathrm{ml})$ for $2 \mathrm{~h}$. A control was incubated only in ASW. After $2 \mathrm{~h}$ the eggs were exposed to ${ }^{3} \mathrm{H}$-leucine $(24 \mu \mathrm{Ci} / \mathrm{ml})$ for $30 \mathrm{~min}$ in the presence of the drug. The control was incubated with the isotope but not puromycin. After 30 min the label and puromycin were removed and the eggs washed 4 times with ice-cold ASW. Samples were then homogenized and analyzed. All points are mean values from 5 replicates; horizontal lines about each point indicate \pm 1 standard error.

repression. At the concentrations of puromycin used first cleavage was inhibited and development arrested at various stages of pre-mitotic meiosis depending upon concentration and length of exposure to the drug. However, when the puromycin was removed, some eggs did continue meiosis but only a few of those treated at the lowest concentration cleaved. The effect of puromycin on protein synthesis is interesting since at the highest concentrations used only about $60 \%$ of the incorporation of labelled leucine into protein is repressed. The failure to reach higher levels of inhibition could be due to
(1) the very unlikely interconversion of ${ }^{3} \mathrm{H}$ leucine and its subsequent incorporation into a hot TCA-organic solvent insoluble product, (2) some protein synthesis not susceptible to puromycin, (3) the inability of the drug to reach all sites of protein synthesis such as nucleus, mitochondria, or other "compartments", or (4) the inability of sufficient amounts of puromycin to enter the egg. The data presented do not provide evidence concerning these alternatives. Collier [2] has reported a repression of $50-80 \%$ in Ilyanassa but does not indicate the stage at which the embryos were treated or the concentrations used. MacKintosh \& Bell [1] report similar low levels of inhibition with cycloheximide in sea urchins.

I thank Dr James N. Cather for the use of his laboratory and for his continuing help and encouragement, and Dr Alberto Monroy for his advice and stimulation during the Fertilization and Gamete Physiology training program.

This work was supported in part by NIH grant 5T01 GM00989.

\section{REFERENCES}

1. Bell, E \& Reeder, R, Biochim biophys acta 142 (1967) 236.

2. Collier, J \& Schwarz, R, Exptl cell res 54 (1969) 403.

3. Gould, M, Dev biol 19 (1969) 482.

4. Lowry, O, Rosebrough, N J, Farr, A L \& Randall, R J, J biol chem 193 (1951) 265.

5. MacKintosh, F R \& Bell, E, J mol biol 41 (1969) 365.

6. Monroy, A \& Tolis, H, Biol bull 126 (1964) 456.

7. Monroy, A \& Vittorelli, M L, J cell comp physiol 60 (1962) 258 .

8. Nakano, E \& Monroy, A, Exptl cell res 14 (1958) 236.

Received September 23, 1969

Revised version received November 10, 1969 